\title{
Effectiveness of a Selfhood Builder Program in Improving Selfhood for a Six-Year-Old Child
}

\author{
Sonia Utari Alatan ${ }^{\mathrm{a}}$ and Farida Kurniawati ${ }^{\mathrm{b}}$ \\ ${ }^{a}$ Faculty of Psychology, Universitas Indonesia, Depok, Indonesia; ${ }^{b}$ Department of Educational \\ Psychology, Faculty of Psychology, Universitas Indonesia, Depok, \\ *Corresponding Author: \\ Farida Kurniawati \\ Educational Psychology Department \\ Faculty of Psychology, Universitas Indonesia \\ Jl. Lkr. Kampus Raya, Depok, Jawa Barat \\ Indonesia, 16424 \\ Tel.: +62 217270004 \\ E-mail: farida1@ui.ac.id
}




\title{
Effectiveness of a Selfhood Builder Program in Improving Selfhood for a Six-Year-Old Child
}

\begin{abstract}
This research aimed to investigate the effectiveness of using a selfhood builder to improve selfhood as one component of self-esteem in children aged six. As a child's foundation of courage to try new things, self-esteem supports children by giving them confidence to explore the environment. Because of the importance of self-esteem in a child of this age, this research focused on selfhood and self-esteem in a girl with a self-esteem problem. An intervention program was administered in four sessions of 4555 minutes per session within one week. Measurement for the program intervention was reflected by two success indicators. Any increase in the number of indicators for selfhood fulfilled before and after the program was the first indicator of success, and it was measured before and after each session. Second, to evaluate each session, the achievement of the objectives from each session was measured. The results showed an increase from 11 indicators before the program to 17 indicators after the program's completion. The indicators for success within each session were also fulfilled. Based on the results, a selfhood builder can improve selfhood in a six-year-old child. Implementation of similar programs in the future could be done by doing a follow-up or further development of design and intervention settings.
\end{abstract}

Keywords: self-esteem; selfhood, selfhood-builder, 6-year-old child

\section{Introduction}

Transitioning from preschool into elementary school requires children to be supported by school readiness, which refers to having the appropriate physical, emotional, and cognitive skills to participate in learning at school (Rafoth, Buchenauer, Crissman, \& Halko, 2004). Ionescu and Benga (2007) add pre-academic skills to the list of what the child needs for school readiness. Among the intellectual, social-emotional, and behavior skills that provide school readiness (Soshami \& Aviv, 2012), social-emotional skills have the biggest role in a child's adaptation to school (California Department of Education, 2008). Social-emotional development is the foundation that is directly related to the development of intellectual skills behaviors (Denham, et. al, 2003, cited in Henniger, 2013). Higher social-emotional skills support children's memory, attention, planning, and other high cognitive processes (Blair, 2002 cited in Denham, 2007). Social-emotional skills include learning social abilities, interpersonal social abilities, emotional abilities (Ionescu \& Benga, 2007), and independence (Morrison, 2009).

At the age of transition to elementary school, children start to develop their concepts of pride and shame; these become the basis for the child's competence in attempting to do new things (Jennings, 2003). The value of a child's competency in this instance is known as self-esteem (Bandura, 2001; Crocker \& Park, 2012 cited in Oyserman, Elmore, \& Smith, 2012). Children with low self-esteem tend to have academic problems at school due to lack of motivation (Alpay, 2002). Furthermore, these children show increasing tendencies toward alcohol use, suicide, and psychological disorders due to the higher stress levels that they encounter in the higher education levels (Emler, 2001). On the other hand, children with high self-esteem tend to have better mental health, openness to the social environment, and higher self-confidence (James, 2002). 
Problems in the academic field can arise when there is a gap between a child's value of competence and his or her actual competence, especially at higher education levels. During the early childhood stage, children are entirely convinced about what others understand about them, so self-esteem at this age affects a child's awareness of his abilities and emotional preparedness in the face of new experiences or challenges (Alpay, 2002). Children have limited predictive vision caused by the tendency to focus on here and now conditions; this also impacts children's self-esteem (Boys \& Girls Clubs of America, 2004). Preventive efforts are needed to prepare a child for the transition because his belief in himself during early childhood tends to transfer into his future beliefs (Alpay, 2002).

Borba (2001) revealed five components of self-esteem: security, selfhood, affiliation, mission, and competence. Based on these components of self-esteem, Borba (1989) created an esteem builder program that is effective in improving self-esteem in children and adolescents. The Borba esteem builder program is divided according to the five components of self-esteem and the associated building steps (Borba, 1989). Various intervention efforts have also proven to be effective in improving self-esteem. Guindon (2010b) discloses several efforts that can improve self-esteem, such as social support, behavioral cognitive strategies, individual counseling strategies, physical fitness enhancement strategies, and other strategies that take the subject's characteristics into account in the intervention. Based on the subject's characteristics in this study, which were shyness, a tendency to speak softly, and inability to stand up in front of the class, the provision of social support became evident as the most appropriate strategy for this child. Social support is classified as effective using a client-centered approach that enables the client to help bridge his actual self with his ideals. Providing social support to children requires involvement by parents, teachers, and any other adults who are close to the child and can enhance feelings of self-worth and help to overcome feelings of failure (Guindon, 2010b). Moreover, social support is important in the formation of children's self-esteem (Green \& Kolos, 2010).

According to Borba (1989), the problem of self-esteem in the subject can be focused on one or two or even five aspects of self-esteem, depending on the subject's individual characteristics. The five components of self-esteem are sequential steps in the cycle, so each component affects and sustains the next one. Security is another prerequisite component of self-esteem. Selfhood, affiliation, mission, and competence will follow based on feeling secure. However, it is possible to perform a combination of activities for the other components in order to improve one component (Borba, 1989). Based on the security measurement checklist, the subject in this study was already able to do almost the whole list of activities (9 of 10), in contrast with the selfhood component (5 of 11). Based on these measurements, the program will focus on the selfhood component; that is, gaining an accurate understanding of oneself according to its real and actual condition. The program chosen is based on the selfhood component of Borba's esteem builder (1989). In addition, because of the effectiveness and the importance of social support in the formation of children's self-esteem, the Borba program (1989) will be supplemented by social support during the intervention sessions. Therefore, the program selected for the subject in this study is a combination of the selfhood component in Borba's esteem builder and social support, which will be called the selfhood builder.

Self-esteem is a person's response to the experience of social support (Kinnunen, Feldt, Kinnunen, and Pulkkinen, 2008, cited in Guindon, 2010b). Based on this understanding, social 
support can improve someone's subjective quality of life, both in the psychological and social areas (Kuehner \& Buerger, 2005, cited in Guindon, 2010b). Guindon (2010b) also discloses that social support provided using a client-centered approach will have a positive impact by connecting the client's actual self and ideal self. Involving parents or other people who are connected to the child will also help the child deal with every failure that happens in the process (Guindon, 2010b). Furthermore, social support is important in building a child's self-esteem (Green \& Kolos, 2010). Berndt (2002) also revealed that the quality of social relationships has a direct effect on several aspects of social development, including self-esteem.

The purpose of the present study is to examine the implementation of the selfhood builder program in a six-year-old child. The selfhood builder program was modeled after the selfhood component in Borba's esteem builder. Additionally, social support was added as another component shown to be important in improving children's self-esteem.

\section{Methods}

\section{Participant}

Subject selection was done through non-probability sampling with a purposive sampling technique. Purposive sampling is a subject selection technique that aligns with the study objectives so that samples could be obtained in accordance with predetermined criteria (Singh, 2007).

The subject in this study was $\mathrm{S}$, a six-year-old girl with self-esteem problems. With good physical ability and a good level of intelligence, the school still complained about her performance, which was based on her social-emotional inability. The results of the previous assessment also show that $\mathrm{S}$ has average-level intelligence, with adequate gross and fine motor skills. Based on the in-class observation, $\mathrm{S}$ seemed to take longer than her friends to copy text from the assignment book. The duration of her work process also seemed to be due to her habit of repeatedly removing the results of her work and doing it over. In addition, $\mathrm{S}$ also tended to wait for her friend to start the task given by the teacher before she started it herself. $\mathrm{S}$ receives acceptance from her surroundings and was favored in groups. S was able to work with groups, but she seemed to be more involved when doing self-tasks together with her classmates. S shows a positive attitude with neither intrusive nor destructive behavior.

With regard to independence, $\mathrm{S}$ had the courage to stand in front of the class when her teacher asks her to, but when asked to speak in front of the class her voice could not be heard. Similarly when the teacher asked the whole class a question, $\mathrm{S}$ only responded if he directly asked her to answer it. That is, she tends not to answer at all when the teacher directs a question to all the children in the classroom. When asked to sing together, her voice also tends to not be heard. S revealed that she felt embarrassed when she was standing in front of the class so her voice was low. Her feeling of embarrassment caused her to be afraid of being laughed at by her friend when she expressed her opinion. According to $S$, other friends will usually laugh if the friends who are up front express a funny opinion. Therefore, the sound of S's voice indicates that $S$ had less confident in her ability. The absence of an accurate understanding of one's ability to express oneself is one component of self-esteem (Alpay, 2002), which is selfhood (Borba, 2001). 


\section{Research Design}

An A-B single-subject design was used. A single case research design is a study using one or a small group as the research subject (Nock, Michel, \& Photos, 2007). Gravetter \& Forzano (2012) revealed that measurement of a program for a single case research A-B design type must be performed before and after program implementation. Nock, Michel and Photos (2007) revealed that single case study designs have advantages in terms of yield strength, flexibility, and efficiency in research conducted in natural settings as a basis for generalizing or evaluating hypotheses in settings, populations or other conditions.

Borba (2001) reveals several steps that are required to improve selfhood. First is to strengthen an accurate self-description. Next, is to continue by providing an opportunity to discover what things affect one's selfhood. The third step is to build an awareness of the unique qualities of the self. Last, but not least, is to improve the ability to identify and express emotions and attitudes. The objectives for each session will be referred by these steps.

\section{Context}

The program was held in school using a classroom after school hours. The subject's school, where the program was implemented, is a private school with complete and comfortable facilities. S was able to be in her own classroom (or in the class next to it) and was free to engage in relaxed activities. Before each session began, she was invited to have lunch first, to refresh herself after the day's school activities.

\section{Approvals}

Approval for this research study was obtained from the principal, who is the person in charge of school permissions, from the parents, who signed an informed consent, and also from the child, whose engagement was required in all the sessions. The informed consent form was read, discussed, and signed by the parents before beginning the program. The approvals from the principal and the child were done by mutual verbal agreement.

\section{Measures}

Program effectiveness was measured by two measurement types. The first measurement was a selfhood behavioral checklist (Borba, 1989). The checklist consisted of ten items that were broken down into 20 indicators, each with its own operational definition. The administration of the checklist was supervised by a certified psychologist. The behavioral checklist was administered before and after each of the four sessions. Borba (1989) does not provide a key success indicator for its program; therefore, any increase in score from the first measurement is an indication of the program effectiveness. As seen in Table 1, the second measurement was added by checking whether the success indicator for each session was reached. This measurement can also act as an evaluation of the implementation of each session in the program.

Table 1

Success Indicator by Each Session

\begin{tabular}{ll}
\hline Sessions & Success Indicator \\
\hline Session 1 & $\begin{array}{l}\text { The child is able to describe herself according to her condition on that day } \\
\text { The child is able to describe the picture that she made by mentioning a pre-made description } \\
\text { Session } 2\end{array}$ \\
$\begin{array}{l}\text { The child is able to fill the available boxes with pictures or writings about the various events she has } \\
\text { experienced } \\
\text { The child is able to tell stories according to her work }\end{array}$ \\
\hline
\end{tabular}


Table 1, cont.

Success Indicator by Each Session

\begin{tabular}{ll}
\hline Sessions & Success Indicator \\
\hline Session 3 & The child is able to complete the image provided in accordance with her ability and unique characteristics \\
& The child is able to tell stories according to her work \\
The child is able to identify the feelings experienced by a given character or image (happy, sad, angry, \\
embarrassed) \\
The child is able to describe her own emotional experiences (happy, sad, angry, scared / embarrassed) \\
The child is able to pair the image in the appropriate place on Worksheet 4
\end{tabular}

Table 2

The List of Materials

Session 1

Tools: Worksheet 1, stationery, colored pencils, picture of the child

Session 2

Tools: Worksheet 2, stationery, colored pencils

Session 3

Tools: Worksheet 3, stationery

Session 4

Tools: Worksheet 4

\section{Procedure}

The program was given in four sessions within one week where each session was 45-55 minutes long (Table 3).

Table 3

The List of Sessions

Session 1

Name of the Session: It's Me

Purpose: Increase self-understanding of physical characteristics

Topic: Child's physical appearance

Time: Day 1 (45 minutes)

Session 2

Name of the Session: My Story

Purpose: Increase your child's awareness of an event (e.g., memorable experience, interesting events)

Topic: A memorable self-experience

Time: Day 2 (50 minutes)

Session 3

Name of the Session: My Identity

Purpose: Increase child's selfhood

Topic: What children like and/or can do

Time: Day 3 (45 minutes)

Session 4

Name of the Session: My Emotion

Purpose: Helping children identify emotions and raise their awareness of their feelings

Topic: Emotions (happy, sad, angry, frightened, embarrassed)

Time: Day 4 (55 minutes)

\section{Interventions}

Because this program was for a child, the actual implementation of each session was kept flexible, so that it could be made shorter or longer as needed to help her finish the tasks assigned for that session. Considering the importance of social support, it was important to support each individual success in order to encourage her to try harder. The intervention program included 195 minutes of face-to-face meetings conducted over four days a week; each session was 40-55 minutes in duration. Guidance and presentation were used to deliver the program. 
Table 4

Intervention Program

\begin{tabular}{llll}
\hline Day and Location & Time & Activity & Duration \\
\hline Tuesday (Day 1) & $09.00-10.30$ & Pretest & 50 minutes \\
Class Room 1A & & Session 1 & 40 minutes \\
Wednesday (Day 2) & $10.00-10.45$ & Session 2 & 45 minutes \\
Class Room 1B & & & 45 minutes \\
Thursday (Day 3) & $10.00-10.45$ & Session 3 & 20 minutes \\
Class Room 1B & & & 40 minutes \\
Friday (Day 4) & $10.00-11.00$ & Session 4 & Posttest \\
Class Room 1A & & & \\
\hline
\end{tabular}

\section{Analysis}

The analysis refers to the measurements taken before and after the program and also before and after each session of the program. Both of these result sets were single data so statistical or visual analysis was not required; that is, making a comparison between the results before and after can be the basis of the conclusion. Further analysis will be done due to the various issues leading to the success or failure of the program or of each session.

\section{Results}

The purpose of the first session was to improve the subject's self-understanding of physical characteristics and self-efficacy. Based on the picture that had been taken that day, S made a picture of herself before she began to describe herself. Her description of herself is focused on her physical appearance. After giving each answer directly one by one, $\mathrm{S}$ was asked to repeat again in front of the class. At first, her tone of voice was hesitant but it became more convincing after the third time. Providing support through praise and enthusiasm for her effort was also done during S's process of completing her task.

The second session's purpose was to increase S's awareness of events from her life, such as a memorable experience, or interesting events that she remembered. $\mathrm{S}$ was asked to draw several pictures of her experiences before sorting the events according to when they happened. When asked to describe her picture, she chose to come to the front of the class and position the paper in front of her face before speaking more loudly than she did in the previous session. She was also willing to repeat her story in front of the class after changing the position of the paper so that it did not cover her face. Her voice sounded essentially the same as before, but the tempo was faster than the first time.

The third session's purpose was an effort to increase S's sense of selfhood. In this session, she was asked to describe anything that she liked or everything she can do. When $\mathrm{S}$ was asked, she immediately ran forward. S also asked if she could be heard from the back of the class when she returned to the front of the class. Her voice was even louder than on the previous two days.

The fourth session's purpose was to help S identify her emotions and raise her awareness of her feelings. Several pictures were shown before she was asked to categorize the emotion shown on each picture. In this task, too, she was supported in her effort to demonstrate she would do when experiencing a certain emotion. This task can be completed quite fast, before the session's time limit is up. Without further guidance, she was able to categorize three basic emotions correctly: happy, sad, and embarrassed. 
The results of the program implementation, after completing four sessions in a week, can be seen in Table 5 and Table 6 . The result of the behavioral checklist result (Table 5) shows an increase from 11 to 17 indicators. Moreover, each intervention session also met the success indicator (Table 6). Therefore, the selfhood builder program can be said to have improved her selfhood.

Table 5

Behavior Checklist Results Before and After Intervention

\begin{tabular}{|c|c|c|c|c|}
\hline No & Indicator & Explanation of Indicators & Before Intervention & After Intervention \\
\hline 1 & $\begin{array}{l}\text { Uncomfortable with } \\
\text { physical appearance }\end{array}$ & $\begin{array}{l}\text { Does not like her body parts } \\
\text { (eyes, nose, mouth, skin, hair, } \\
\text { etc.) }\end{array}$ & $\begin{array}{l}\text { S dislikes her teeth because } \\
\text { there are some teeth that are } \\
\text { not in good shape. }\end{array}$ & S liked all parts of her body. \\
\hline \multirow[t]{3}{*}{2} & $\begin{array}{l}\text { Child has difficulties } \\
\text { receiving praise }\end{array}$ & $\begin{array}{l}\text { Doesn't know what to do when } \\
\text { receiving praise (passive) }\end{array}$ & $\begin{array}{l}\text { S understands that she should } \\
\text { respond to any praise, but she } \\
\text { just stays silent. }\end{array}$ & $\begin{array}{l}\text { S thanked her school security } \\
\text { guard when he praised her }\end{array}$ \\
\hline & $\begin{array}{l}\text { The child avoids receiving } \\
\text { any compliment }\end{array}$ & $\begin{array}{l}\text { Displays withdrawing, distracting } \\
\text { behavior when receiving praise }\end{array}$ & $\begin{array}{l}\text { S did not withdraw or act } \\
\text { distracted }\end{array}$ & $\begin{array}{l}\text { S did not withdraw or act } \\
\text { distracted }\end{array}$ \\
\hline & $\begin{array}{l}\text { The child displays } \\
\text { embarrassed behavior } \\
\text { when receiving praise }\end{array}$ & $\begin{array}{l}\text { For example, hiding, avoiding } \\
\text { eye contact, speaking very quietly } \\
\text { when receiving praise }\end{array}$ & $\begin{array}{l}\text { S was not hiding or avoiding } \\
\text { eye contact. S claims that she } \\
\text { has answered already, but her } \\
\text { voice wasn't heard. }\end{array}$ & $\begin{array}{l}\text { S was not hiding or avoiding } \\
\text { eye contact. } S \text { even thanked the } \\
\text { school security guard after his } \\
\text { praise. }\end{array}$ \\
\hline \multirow[t]{3}{*}{3} & $\begin{array}{l}\text { Child follows the behavior } \\
\text { of others }\end{array}$ & $\begin{array}{l}\text { Use other people that are around } \\
\text { as an example of how to behave }\end{array}$ & $\begin{array}{l}\mathrm{S} \text { greets the person she meets } \\
\text { after being asked or told what } \\
\text { to do. }\end{array}$ & $\begin{array}{l}\text { S greets the person she meets } \\
\text { after being asked or told what } \\
\text { to do. }\end{array}$ \\
\hline & $\begin{array}{l}\text { Child had difficulty } \\
\text { expressing herself in her } \\
\text { own way }\end{array}$ & $\begin{array}{l}\text { Passive; for example, doesn't } \\
\text { respond even if she knew the } \\
\text { answer }\end{array}$ & $\begin{array}{l}\mathrm{S} \text { was able to express what she } \\
\text { wants personally. }\end{array}$ & $\begin{array}{l}\mathrm{S} \text { was able to express what she } \\
\text { wants personally. }\end{array}$ \\
\hline & $\begin{array}{l}\text { Child had difficulty taking } \\
\text { risks or looking different }\end{array}$ & $\begin{array}{l}\text { For example, she copied the } \\
\text { behavior or followed the opinions } \\
\text { of others around her }\end{array}$ & $\begin{array}{l}\mathrm{S} \text { tends to follow the behavior } \\
\text { of others around her. }\end{array}$ & $\begin{array}{l}\mathrm{S} \text { tends to follow the behavior } \\
\text { of others around her. }\end{array}$ \\
\hline 4 & $\begin{array}{l}\text { Unseasonable, such as } \\
\text { eccentric clothing or } \\
\text { searching for attention in } \\
\text { class }\end{array}$ & $\begin{array}{l}\text { For example, wearing a uniform } \\
\text { with eye-catching additional } \\
\text { attributes, deliberately displaying } \\
\text { behavior that was not in } \\
\text { accordance with the situation or } \\
\text { social norms }\end{array}$ & $\begin{array}{l}\mathrm{S} \text { dressed in accordance with } \\
\text { the school's rules. }\end{array}$ & $\begin{array}{l}\mathrm{S} \text { dressed in accordance with } \\
\text { the school's rules. }\end{array}$ \\
\hline \multirow[t]{2}{*}{5} & $\begin{array}{l}\text { Having difficulty } \\
\text { expressing emotions }\end{array}$ & $\begin{array}{l}\text { Showing off her emotions in an } \\
\text { inappropriate way (such as a } \\
\text { tantrum or shouting in anger) }\end{array}$ & $\begin{array}{l}\mathrm{S} \text { was able to show emotions in } \\
\text { the appropriate way. }\end{array}$ & $\begin{array}{l}\mathrm{S} \text { was able to show emotions in } \\
\text { the appropriate way }\end{array}$ \\
\hline & $\begin{array}{l}\text { Have difficulty in } \\
\text { identifying emotions }\end{array}$ & $\begin{array}{l}\text { Can't recognize the signs of } \\
\text { certain emotions (e.g. happy - } \\
\text { smile, crying or sadness - sad) }\end{array}$ & $\begin{array}{l}\mathrm{S} \text { was able to recognize signs } \\
\text { for happy, sad, angry, scared. }\end{array}$ & $\begin{array}{l}\text { S was able to recognize signs } \\
\text { for happy, sad, angry, scared. }\end{array}$ \\
\hline \multirow[t]{4}{*}{6} & $\begin{array}{l}\text { Having inaccurate } \\
\text { self-role information }\end{array}$ & $\begin{array}{l}\text { Looking at the child's ability to } \\
\text { describe herself (e.g., when } \\
\text { describing her family, the child's } \\
\text { understanding of her role as a } \\
\text { child, sibling, and gender) }\end{array}$ & $\begin{array}{l}\mathrm{S} \text { was able to tell that she lives } \\
\text { with her parents and brother. }\end{array}$ & $\begin{array}{l}\mathrm{S} \text { was able to tell that she lives } \\
\text { with her parents and brother. }\end{array}$ \\
\hline & $\begin{array}{l}\text { Having inaccurate } \\
\text { information about } \\
\text { self-nature }\end{array}$ & $\begin{array}{l}\text { For example diligent (judged by } \\
\text { the work of homework or task), } \\
\text { clever (repetition or assignment) }\end{array}$ & $\begin{array}{l}\text { S always does her homework. } \\
\text { Even though she thought that } \\
\text { she was clever, her test results } \\
\text { were not as good as she } \\
\text { thought they would be. }\end{array}$ & $\begin{array}{l}\text { S always does her homework. } \\
\text { Even she thought that she was } \\
\text { clever and able to do the } \\
\text { final-term test. }\end{array}$ \\
\hline & $\begin{array}{l}\text { Have less accurate } \\
\text { self-information }\end{array}$ & $\begin{array}{l}\text { For example about favorite } \\
\text { places, activities, or other things } \\
\text { most liked or disliked }\end{array}$ & $\begin{array}{l}\text { S understands the things she } \\
\text { likes. }\end{array}$ & $\begin{array}{l}\text { S understands the things she } \\
\text { likes. }\end{array}$ \\
\hline & $\begin{array}{l}\text { Having inaccurate } \\
\text { physical self- } \\
\text { characteristic information }\end{array}$ & $\begin{array}{l}\text { For example by depicting large } \\
\text { eyes, white skin, long hair, etc. }\end{array}$ & $\begin{array}{l}\mathrm{S} \text { was able to describe her } \\
\text { characteristics according to her } \\
\text { condition. }\end{array}$ & $\begin{array}{l}\mathrm{S} \text { was able to describe her } \\
\text { characteristics according to her } \\
\text { condition. }\end{array}$ \\
\hline \multirow[t]{2}{*}{7} & $\begin{array}{l}\text { Anxious excessive } \\
\text { interaction with others }\end{array}$ & $\begin{array}{l}\text { For example, complaining about } \\
\text { the opinions of friends or teachers } \\
\text { related to her }\end{array}$ & $\begin{array}{l}\text { S complained about her friends } \\
\text { who played rough or did not } \\
\text { speak appropriately. }\end{array}$ & $\begin{array}{l}\text { S complained about her friends } \\
\text { who played rough or did not } \\
\text { speak appropriately. }\end{array}$ \\
\hline & $\begin{array}{l}\text { Reliance related to social } \\
\text { relations }\end{array}$ & $\begin{array}{l}\text { For example can't perform } \\
\text { activities independently (doing } \\
\text { homework, permission to go to } \\
\text { the bathroom) }\end{array}$ & $\begin{array}{l}\mathrm{S} \text { was able to do her own } \\
\text { homework. } \mathrm{S} \text { was able to go to } \\
\text { the bathroom alone. }\end{array}$ & $\begin{array}{l}\mathrm{S} \text { was able to do her own } \\
\text { homework. } \mathrm{S} \text { was able to go to } \\
\text { the bathroom alone. }\end{array}$ \\
\hline
\end{tabular}


Table 5, cont.

Behavior Checklist Results Before and After Intervention

\begin{tabular}{|c|c|c|c|c|}
\hline No & Indicator & Explanation of Indicators & Before Intervention & After Intervention \\
\hline \multirow[t]{2}{*}{8} & $\begin{array}{l}\text { Often use negative } \\
\text { environmental statements }\end{array}$ & $\begin{array}{l}\text { Asking children's opinions about } \\
\text { their surroundings, such as their } \\
\text { likes or dislikes with teachers, } \\
\text { friends, schools }\end{array}$ & $\begin{array}{l}\text { S doesn't like her classmates } \\
\text { who were angry or did not } \\
\text { listen when S wanted to tell } \\
\text { them something. }\end{array}$ & $\begin{array}{l}\text { S describes that her classmates } \\
\text { were good already, so she liked } \\
\text { her classmates. }\end{array}$ \\
\hline & $\begin{array}{l}\text { Too sensitive in accepting } \\
\text { criticism }\end{array}$ & $\begin{array}{l}\text { Asking the child's opinion about } \\
\text { her response when asked to } \\
\text { correct incorrect writing or } \\
\text { reprimand (whether negative as } \\
\text { angry or rejecting, or as positive } \\
\text { as obeying) }\end{array}$ & S will obey when reprimanded. & S will obey when reprimanded. \\
\hline 9 & $\begin{array}{l}\text { Uncomfortable with both } \\
\text { rough and smooth motor } \\
\text { activity }\end{array}$ & $\begin{array}{l}\text { Asking children's opinions about } \\
\text { whether children like or dislike } \\
\text { rough motor activities (running, } \\
\text { jumping, dancing, etc.) or fine } \\
\text { motor activities (writing, cutting, } \\
\text { sticking, etc.) }\end{array}$ & $\begin{array}{l}\text { S enjoys both rough and } \\
\text { smooth motor activity. }\end{array}$ & $\begin{array}{l}\text { S enjoys both rough and } \\
\text { smooth motor activity. }\end{array}$ \\
\hline 10 & $\begin{array}{l}\text { Feeling not good enough } \\
\text { or special }\end{array}$ & $\begin{array}{l}\text { Asking the child to compare } \\
\text { herself with others around her } \\
\text { (for example what distinguishes } \\
\text { the child from others around her) }\end{array}$ & $\begin{array}{l}\text { S cannot find anything that } \\
\text { distinguishes herself from } \\
\text { others around her. }\end{array}$ & $\begin{array}{l}\text { S reveals that her painting was } \\
\text { better than her friend's. S also } \\
\text { can run faster than her friend. }\end{array}$ \\
\hline
\end{tabular}

Table 6

Table of Results from Each Intervention Session

\begin{tabular}{|c|c|c|c|c|c|}
\hline Session & Session Name & Operational Purpose & Success Indicators & Activity Results & Conclusion \\
\hline \multirow[t]{2}{*}{1} & It's Me & $\begin{array}{l}\text { Improve } \\
\text { self-understanding of } \\
\text { physical } \\
\text { characteristics and } \\
\text { self-efficacy }\end{array}$ & $\begin{array}{l}\text { The child was able to } \\
\text { describe herself } \\
\text { according to her } \\
\text { condition of the day }\end{array}$ & $\begin{array}{l}\mathrm{S} \text { was able to describe } \\
\text { herself according to } \\
\text { her condition that day. }\end{array}$ & Reached \\
\hline & & & $\begin{array}{l}\text { The child was able to } \\
\text { describe the picture } \\
\text { she made }\end{array}$ & $\begin{array}{l}\text { The child was able to } \\
\text { describe her drawing } \\
\text { about herself that she } \\
\text { made earlier. }\end{array}$ & Reached \\
\hline \multirow[t]{2}{*}{2} & My Story & $\begin{array}{l}\text { Increase your child's } \\
\text { awareness of her } \\
\text { events (e.g., } \\
\text { memorable } \\
\text { experience, } \\
\text { interesting events) }\end{array}$ & $\begin{array}{l}\text { The child was able to } \\
\text { fill in the available } \\
\text { boxes with pictures } \\
\text { or writings about the } \\
\text { various events she } \\
\text { has experienced }\end{array}$ & $\begin{array}{l}\text { S was able to fill in the } \\
\text { boxes with pictures or } \\
\text { sentences about the } \\
\text { various events she has } \\
\text { experienced }\end{array}$ & Reached \\
\hline & & & $\begin{array}{l}\text { Child was able to tell } \\
\text { stories according to } \\
\text { her work }\end{array}$ & $\begin{array}{l}\text { S was able to describe } \\
\text { her work }\end{array}$ & Reached \\
\hline \multirow[t]{2}{*}{3} & My Identity & $\begin{array}{l}\text { Increase the child's } \\
\text { selfhood }\end{array}$ & $\begin{array}{l}\text { Child was able to } \\
\text { complete the image } \\
\text { provided in } \\
\text { accordance with her } \\
\text { condition }\end{array}$ & $\begin{array}{l}\text { S was able to complete } \\
\text { the image provided in } \\
\text { accordance with her } \\
\text { condition }\end{array}$ & Reached \\
\hline & & & $\begin{array}{l}\text { Child was able to tell } \\
\text { stories according to } \\
\text { her work }\end{array}$ & $\begin{array}{l}\mathrm{S} \text { was able to make } \\
\text { stories from her work }\end{array}$ & Reached \\
\hline \multirow[t]{2}{*}{4} & My Emotion & $\begin{array}{l}\text { Helping children } \\
\text { identify emotions and } \\
\text { raise children's } \\
\text { awareness of their } \\
\text { feelings }\end{array}$ & $\begin{array}{l}\text { The child was able to } \\
\text { identify the feelings } \\
\text { experienced by a } \\
\text { given character or } \\
\text { image (happy, sad, } \\
\text { angry, embarrassed) }\end{array}$ & $\begin{array}{l}\text { S was able to identify } \\
\text { the feelings seen in a } \\
\text { given image }\end{array}$ & Reached \\
\hline & & & $\begin{array}{l}\text { The child was able to } \\
\text { tell about her } \\
\text { emotional } \\
\text { experiences (happy, } \\
\text { sad, angry, scared/ } \\
\text { embarrassed) }\end{array}$ & $\begin{array}{l}\text { The child was able to } \\
\text { describe expressions } \\
\text { of certain feelings } \\
\text { (happy, sad, angry, } \\
\text { fear / embarrassment) }\end{array}$ & Reached \\
\hline
\end{tabular}




\section{Discussion}

From the child's development point of view, parenting style also plays an important role in school readiness. Fitzpatrick (2011) reveals that children need to develop positive psychosocial skills and hard-working habits to be able to cope with an academic transition period in school. S's parents confused her when entering the new environment because they employed a permissive parenting style, presumably in hopes of providing comfort or security. S's perceived confusion caused her to show a lack of initiative tended to make her wait for directions before acting in the new environment. This adds urgency to the importance of program implementation for $\mathrm{S}$; she needs assistance in facing and navigating the various environmental changes around her.

Preparation of the selfhood builder program was done by referring to the esteem builder program developed by Borba (1989) and the use of social support specifically as an additional focus. Although Borba's (1989) esteem builder program did not have any special emphasis on the role of social support, studies by Green and Kolos (2010) showed the effectiveness of social support on improving self-esteem in children. Based on these considerations, the selfhood builder program was compiled and has proven effective in improving self-esteem in components of selfhood. With better selfhood, hopefully another component of self-esteem can be improved, because selfhood will be the prerequisite of affiliation, mission, competence, and also security and selfhood again as part of the cycle of interrelated self-esteem components.

Although the program has been reviewed by three expert psychologist judges with more than five years' experience in the field of child intervention, there is room for improvement in the design of the program. For example, the program could be developed with more variation in activity based on particular children's characteristics, such as using puppet shows in addition to writing and drawing. Other than that, due to limited time, the validity improvement from several trials for each session cannot be done, which become the limitation of this study. Moreover, the trials for each session will result in improvement and revision to improve future implementations (Fraser \& Gallinsky, 2010).

The results of this study indicate that the selfhood builder program based on Borba's esteem builder (1989), with the addition of social support, increased the number of behavior indicators from 11 to 17 for this subject. Although the results obtained were positive, the improvement from the intervention can't be generalized since there is no effect size calculation (Odom, 2009, cited in Parker, 2011). An effect size calculation cannot be obtained because effect size can only be done with an ABA research design (Beeson \& Robey, 2006), or by requiring multiple measurements before and after the intervention (Parker, 2011).

Proven to be effective, the selfhood builder program is still limited to the individual classroom setting for interventions. Empirical evidence has not been obtained from intervention programs in real or day-to-day situations. A good intervention program includes three phases: the diagnosis assessment, the implementation of the intervention, and the follow-up assessment (NCTM, 2007). This program did not include follow-up, so further research is needed to evaluate the intervention program and the extent to which $\mathrm{S}$ is able to utilize the results of her intervention in her everyday life. 


\section{References}

Alpay, E. (2002). Self-concept and self-esteem. London: Imperial College of Science, Technology and Medicine.

Beeson, P. M., \& Robey, R. R. (2006). Evaluating single-subject treatment research: Lessons learned from the aphasia literature. Neuropsychology Review, 16(4), 161-169.

Berndt, T. J. (2002). Friendship quality and social development. Current Direction in Psychological Science, 11(1), 7-10.

Borba, M. (1989). Esteem builders: A K-8 self-esteem curriculum for improving student achievement, behavior and school climate. California, CA: Jalmar Press.

Borba, M. (2001, 2009). The five building blocks of self-esteem. Retrieved October 2014, 27 th from http://micheleborba.com/the-five-building-blocks-of-self-esteem/

Boys \& Girls Clubs of America. (2004). Developmental characteristics of youth. Program basic: The definitive program resource for boys \& girls clubs. Retrieved August $\quad 7^{\text {th }}, \quad 2014 \quad$ from www.bgcgrandrapids.org\%2Fuploads\%2Ffiles\%2FYouth_Development_Character istics.pdf\&ei=4nezVL7wO8-WuATr8oGIBg\&usg=AFQjCNHsHX8Eqoo2wrQXL4U52r1RT1RsgQ\&sig2=ynGZ94pHYB62 ZHO5_031w\&bvm=bv.83339334,d.c2E

California Departement of Education. (2008). California preschool learning foundations (Vol. 1). Sacramento, CA: California Departement of Education.

Denham, S. A. (2007). Dealing with feelings: How children negotiate the worlds of emotions and social relationships. Cognition, Brain, Behavior, XI(1), 1-48.

Emler, N. (2001). Self-esteem: The cost and causes of low self-worth. York, NY: York Publishing Services.

Fitzpatrick, C. (2011). Kindergarten classroom engagement skills: The road to academic success in elementary school. Unpublished Dissertation, Université de Montréal, Ottawa.

Fraser, M. W. \& Galinsky, M. J. (2010). Steps in intervention research: Designing and developing social programs. Research in Social Work Practice, 20(5), 459-466. DOI:10.1177/1049731509358424

Gravetter, F. J., \& Forzano, L.-A. B. (2012). Research methods for the behavioral sciences (4th ed.). Belmont, CA: Wadsworth.

Green, E. J., \& Kolos, A. C. (2010). Facilitating self-esteem in elementary school-aged children: A child-centered play therapy approach. In M. H. Guindon (Ed.), Self-esteem across the lifespan: Issues and interventions. New York, NY: Routledge Taylor \& Francis.

Guindon, M. H. (2010a). Self-esteem across the lifespan: Issues and interventions. New York, NY: Routledge Taylor \& Francis.

Guindon, M. H. (2010b). What do we know about self-esteem intervention? In M. H. Guindon (Ed.), Self-esteem across the lifespan: Issues and interventions. New York, NY: Routledge Taylor \& Francis.

Henniger, M. L. (2013). Teaching young children: An introduction ( $5^{\text {th }}$ ed.). New Jersey, NJ: Pearson.

Ionescu, T., \& Benga, O. (2007). Reconceptualizing early education on scientific grounds: School readiness in focus. Cognition, Brain, Behavior, XI(11), 49-65.

James, K. (2002). Report and literature review into the role of self-esteem as a barrier to learning and as an outcome: Departement for Education and Skills \& Niace.

Jennings, K. D. (2003). Mastery motivation and the formation of self-concept from infancy through early childhood. In D. J. Messer (Ed.), Mastery motivation in early childhood: Development, measurement and social processes. -: Taylor \& Francis e-Library.

Morrison, G. S. (2009). Early childhood education today ( $7^{\mathrm{t}}$ Edition.). New Jersey, NJ: Pearson EDuxation.

NCTM. (2007). Creating or selecting intervention program [Electronic Version]. Retrieved January $1^{\text {st }}, 2015$ from http://www.nctm.org/uploadedFiles/Lessons_and_Resources/Intervention_Resources/Intervention\%2520Programs\%2520(NC TM,\%2520Nov\%25202007).pdf\&ved=0CC8QFjAG\&usg=AFQjCNFPZPcf_zOdGCYmfuShe0ZxMnuBw\&sig2=bIpOJ6sC ZUZ7LGIzeTf-YQ.

Nock, M. K., Michel, B. D., \& Photos, V. I. (2007). Single-case research designs. In D. McKay (Ed.), Handbook of research methods in abnormal and clinical psychology (pp. 337-350). Thousand Oaks, CA: Sage.

Oyserman, D., Elmore, K., \& Smith, G. (2012). Self, self-concept, and identity. In M. R. Leary \& J. P. Tangney (Eds.), Handbook of self and identity (2nd ed., pp. 69-104). New York, NY: The Guilford Press.

Parker, R. I., Vannest, K. J., \& Davis, J. L. (2011). Effect size in single-case research: A review of nine non overlap techniques. Behavior Modification, $\mathrm{XX}(\mathrm{X}), 1-20$.

Rafoth, M. A., Buchenauer, E. L., Crissman, K. K., \& Halko, J. L. (2004). School readiness - preparing children for kindergarten and beyond: Information for parents. School and home. Retrieved August $7^{\text {th }}$ 2014 from http://www.nasponline.org/resources/handouts/schoolreadiness.pdf\&sa=U\&ei=EfjULcDpaiugTzxoJo\&ved=0CBAQFjAA\&u sg=AFQjCNGKEkRA2Y hMfevn2 lHJYKmgM1gXfQ

Shoshani, A., \& Aviv, I. (2012). The pillars of strength for first-grade adjustment - Parental and children's character strengths and the transition to elementary school. The Journal of Positive Psychology, 1-12.

Singh, K. (2007). Quantitative social research methods. New Delhi: Sage Publications. 